\title{
Natural antiinflammatory agents for pain relief in athletes
}

\author{
Joseph C. Maroon, M.D., Jeffrey W. Bost, P.A.-C., Meghan K. Borden, \\ Keith M. LoRenz, AND Nathan A. Ross \\ Department of Neurosurgery, University of Pittsburgh Medical Center, Pittsburgh, Pennsylvania
}

\begin{abstract}
$\checkmark$ Most athletes experience musculoskeletal injuries during their sports activity that require rest at a minimum, and occasionally injuries are severe enough to necessitate surgical repair. Neurosurgeons are often consulted for athletically sustained injuries and prescribe medications for the associated pain. The use of both over-the-counter and prescription nonsteroidal medications is frequently recommended, but recent safety concerns must now be considered. The authors discuss the biochemical pathways of nonsteroidal drugs and review the potentially serious side effects of these medications. They also review the use of natural supplements, which may be a safer, and often as effective, alternative treatment for pain relief.
\end{abstract}

\section{KEY WORDS • pain • nonsteroidal antiinflammatory drug • cyclooxygenase inhibitor • drug reaction - sports medicine}

$\mathrm{T}$ RAUMATIC arthropathy, discogenic pain, posttraumatic headaches, tendonopathy, peripheral radiculopathy, and neuropathy are all conditions associated with participation in competitive sports. ${ }^{24}$ Pain, heat, redness, and swelling (dolor, calor, rubor, tumor) from these injuries are part of the natural inflammatory process, which can lead to neurosurgical consultation. ${ }^{108}$ With the elucidation of the role of inflammatory cytokines, we now understand the pathways by which many drugs can alleviate inflammation and hence pain. Among those inflammatory cytokines whose interactions with NSAIDs must be understood are IL- $1 \alpha$, IL-1 $\beta$, and TNF $\alpha$. These cytokines inhibit the production of prostaglandins, and therefore it is necessary to determine how they can be influenced by NSAIDs to develop an effective drug. ${ }^{86}$

Unfortunately, NSAIDs may be associated with significant complications, including the following: gastrointestinal hemorrhage, myocardial infarction, and stroke. ${ }^{46,49,154}$ As a result of personal experience with these complications in our patients, including athletes, we investigated the use of natural antiinflammatory agents for neurological sports-related and other injuries. To our surprise, many such compounds are available and have been used effectively for centuries to reduce pain and inflammation. Additionally, we were able to find many peer-reviewed articles and clinical trials attesting to their effectiveness.

Recently the pharmacology of these agents relative to the COX and NF-кB inflammatory pathways has been elucidated. ${ }^{86}$ In many cases the natural agents work in a similar biochemical fashion to pharmacologically derived

Abbreviations used in this paper: $\mathrm{COX}=$ cyclooxygenase; $\mathrm{DHA}=$ docosahexaenoic acid; EFA = essential fatty acid; EPA = eicosapentaenoic acid; FDA = Food and Drug Administration; I $\mathrm{B}=$ inhibitor of $\kappa \mathrm{B}$; IL = interleukin; LOX = lipoxygenase; NF- $\kappa \mathrm{B}=$ nuclear factor $-\kappa \mathrm{B}$; NSAID = nonsteroidal antiinflammatory drug; $\mathrm{TNF} \alpha=$ tumor necrosis factor $-\alpha$. drugs, but without the complications often associated with nonsteroidal medications. In this paper we summarize the current research on the inflammatory pathways, discuss the mechanism of action of various pharmacological and natural products in blocking inflammation, and provide an overview of the most commonly used natural antiinflammatory medications.

\section{Inflammatory Pathways}

\section{The Arachidonic Acid/COX Pathway}

In 1971, Professor John Vane from Cornell University was awarded the Nobel Prize for his work in elucidating the mechanism of action of aspirin on prostaglandins..$^{108}$ Prostaglandins are short-lived localized hormones that can be released by any cell of the body during tissue, chemical, or traumatic injury, and can induce fever, inflammation, and pain once they are present in the intercellular space. ${ }^{63,161}$ Thromboxanes, which are also hormone activators, regulate blood vessel tone, platelet aggregation, and clot formation; are manufactured in every cell of the body; and can be released in response to injury ${ }^{85,135,162}$ There is a complex biochemical pathway which, once stimulated by injury, will lead to the production of these and other inflammatory mediators whose initial effect is pain and tissue destruction, followed by healing and recovery. ${ }^{52,77}$ This is called the arachidonic acid pathway, because arachidonic acid is released in the early stages from traumatized cellular membranes. This substance is transformed into prostaglandins and thromboxanes through the action of COX.52,77,86 Vane ${ }^{164,165}$ discovered that aspirin works by irreversibly disabling the COX enzymes so that they no longer produce the inflammatory prostaglandins and thromboxanes (Fig. 1). Aspirin therefore reduces inflammation, pain, fever, and blood clotting by decreasing prostaglandin and thromboxane production. ${ }^{166}$ 


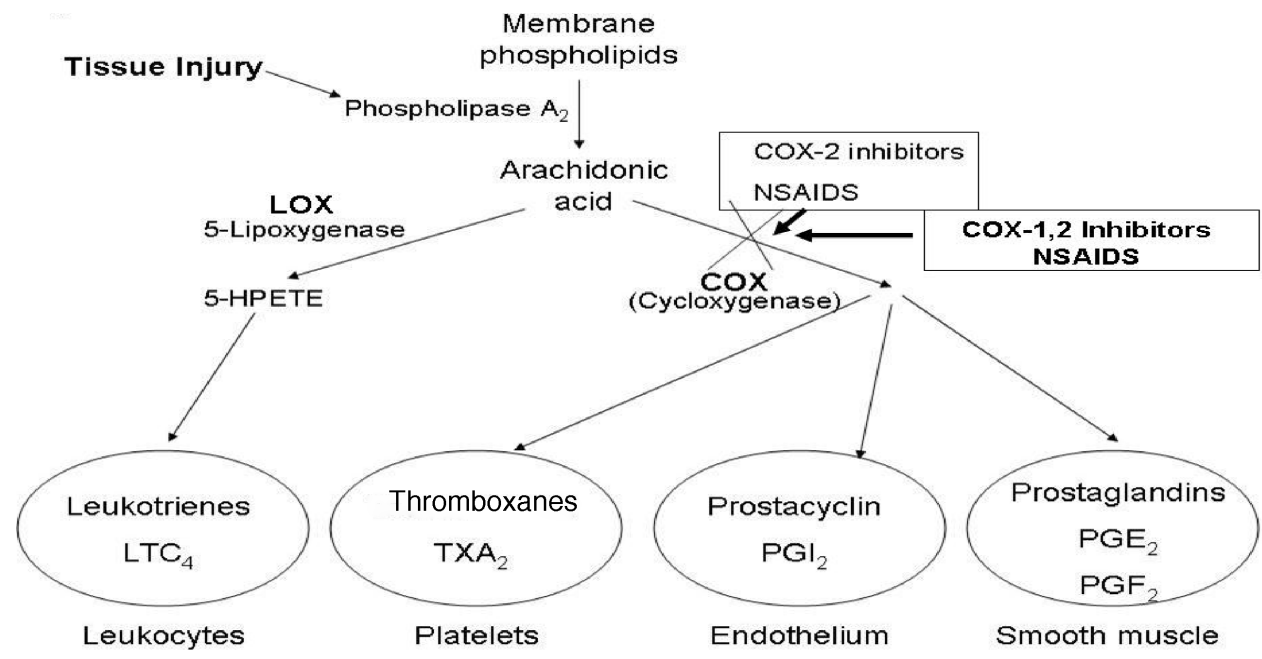

FIG. 1. Schematic showing that when a cell membrane is injured the arachidonic acid pathway is activated to initiate the local inflammatory response through the production of prostaglandins, thromboxanes, and leukotrienes. Their activation, however, requires the enzymes COX and LOX. The NSAIDs can block COX action and thereby prevent the formation of the COX-derived inflammatory mediators. 5-HPETE $=$ 5-hydroperoxyeicosatetraenoic acid; LTC $_{4}=$ leukotriene $\mathrm{C} 4 ; \mathrm{PGE}_{2}=$ prostaglandin $\mathrm{E} 2 ; \mathrm{PGF}_{2}=$ prostaglandin $\mathrm{F} 2 ; \mathrm{PGI}_{2}=$ prostacyclin; $\mathrm{TXA}_{2}=$ thromboxane.

Nonselective COX Inhibitors. The COX enzyme is found in two forms in the human body: COX-1, a constitutive enzyme that normally protects the gastrointestinal mucosa; and COX-2, which is activated by tissue damage and is considered to be an inducible enzyme because it exists during injury only (Fig. 2). . $2,77,113,133,135,148,165$ Gastrointestinal side effects associated with COX inhibitors, such as aspirin and the nonselective NSAIDs, which block both COX-1 and COX-2, have pushed researchers to find a way to block COX-2 selectively and thereby limit the complications of gastritis and ulcers that are common with long-term use. $49,75,86,135,154,172$

Selective COX Inhibitors. In December 1998, celecoxib (Celebrex $)^{25}$ was approved by the FDA as the first selective COX-2 inhibitor for treatment of arthritis pain..$^{36,77,135}$ Rofecoxib (Vioxx) was approved several months later, followed by valdecoxib (Bextra). ${ }^{41,45,105,114,135}$ These NSAIDs were designed to allow continued production of the gas-

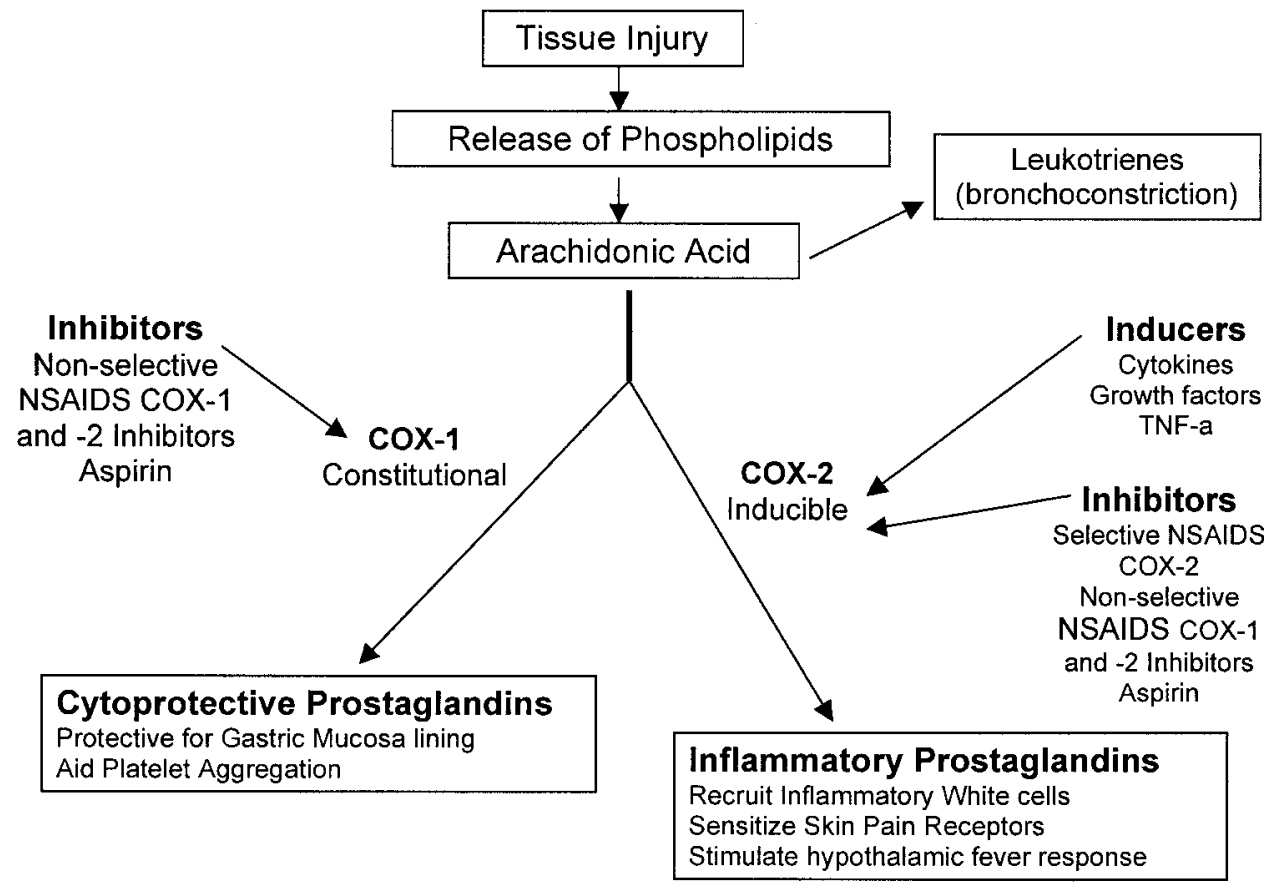

FIG. 2. Schematic showing that the COX enzyme can exist in two forms: COX-1, constitutional or existing in small amounts at all times; or COX-2, inducible or only present during the inflammatory response. By selectively blocking only the COX-2-produced inflammatory prostaglandins, COX-2-inhibiting medications were believed to be superior to nonselective COX-1 and -2 inhibitors, and they were thought to have fewer gastric side effects. 
trointestinally protective prostaglandins produced through the COX-1 enzyme system while blocking the COX-2 enzyme that produces the inflammatory prostaglandins. ${ }^{52,77,114,129}$ The number of prescriptions for nonselective (COX-1 and -2) inhibitors such as ibuprofen (Motrin) quickly dropped as the new selective COX-2-inhibiting NSAIDs began to grow in popularity. ${ }^{66} \mathrm{By}$ its 7 th week on the market, Celebrex had surpassed Viagra in generating record numbers of daily prescriptions early in its marketing. ${ }^{66,80}$ The Big 3 (Celebrex, Vioxx, and Bextra) quickly became the mainstay for the treatment of chronic pain conditions related to inflammation. ${ }^{108}$ Within a few years, an estimated 15 to 20 million people were using selective COX-2-inhibiting NSAIDs on a long-term basis in the US. These drugs became the most commonly used pharmaceutical agent, with more than 70 million NSAID prescriptions written each year and 30 billion over-the-counter NSAID tablets sold annually. It was estimated that 5 to $10 \%$ of the adult population used NSAIDs, and among the elderly (a group at higher risk of NSAID-induced gastrointestinal complications), use of these drugs was as high as $15 \%$. In 2003, the sales of these three drugs surpassed $\$ 9$ billion in the US alone. The general acceptance of these drugs was due to the perceived lack of serious gastrointestinal side effects that had been associated with the nonselective class of NSAIDs. ${ }^{173}$

Side Effects of COX-2 Inhibitors. On September 30, 2004, Merck Research Laboratories announced the global withdrawal of rofecoxib (Vioxx), its primary selective COX2-inhibiting NSAID. ${ }^{23,80,179}$ Analysis of the results of the Adenomatous Polyps Prevention on Vioxx study (known as the APPROVe study) showed that there was double the risk of serious thromboembolic events, including myocardial infarction, which became apparent after 18 months of treatment ${ }^{7,77,127}$ This mechanism of action is based on selectively allowing COX-1 to continue to produce platelet synthesis of thromboxane, a thrombogenic and atherogenic eicosanoid, and at the same time selectively inhibiting COX-2 production of endothelial cell synthesis of prostacyclin, which opposes the effects of thromboxane. ${ }^{54}$ Thus, these drugs that were intended to reduce the levels of inflammatory prostaglandins were now also inhibiting prostacyclin, which led to the development of thrombotic cardiovascular and cerebrovascular events..$^{55,66,148}$ These complications were especially common in patients who were at high risk, such as those who had suffered a previous myocardial infarction or a recent bypass graft or vascular stent placement. ${ }^{47,48,55,127}$ Furthermore, it was shown that not only were the COX-2 inhibitors associated with an increased incidence of myocardial infarction and stroke, but also that there was little improvement in the prevention of gastric ulcers. . $^{52,77,87,127}$

\section{Other Inflammatory Pathways: $N F-\kappa B$ and Cytokines}

Since the discovery of COX in the 1970s, a number of additional pathways have been discovered that are more complex and are associated with persistent or chronic inflammation. The discovery of NF- $\mathrm{BB}$ and how it activates cytokines is critical to our new understanding of the inflammatory process. The NF- $\kappa \mathrm{B}$ molecule is a protein that acts as a switch to turn inflammation on and off in the body. Some researchers refer to the NF- $\mathrm{KB}$ protein as act- ing like a smoke sensor in cells because it is able to detect noxious stimuli, such as infectious agents, free radicals, and other cellular injuries. ${ }^{170}$ In response, it can literally turn on the particular genes that lead to the production of inflammatory cytokines. ${ }^{64}$ The NF- $\kappa \mathrm{B}$ proteins are localized in the cytoplasm of the cell and are associated with a

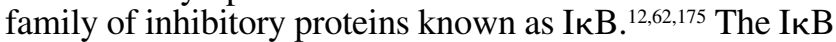
proteins are normally bound to NF- $\kappa \mathrm{B}$ and block their nuclear localization signal. A variety of cytokine stimuli can degrade the IкB and result in the nuclear translocation of NF-кB. These stimuli can include trauma, viral infections, ultraviolet radiation, free radicals, and also the cytokines TNF $\alpha$ and IL-1 $\beta .{ }^{120,175}$ The TNF $\alpha$ and especially IL-1 $\beta$ can also directly stimulate enzymes known as matrix metalloproteinases, which break down extracellular collagen matrix, a hallmark of inflammatory joint disease..$^{50,111,112,156}$ The phosphorylation of the IкB proteins and unbinding of the NF- $\mathrm{KB}$ is the key step involved in the activation of NF- $\kappa \mathrm{B}$, and this is mediated by I $\mathrm{B}$ kinases. ${ }^{175,177}$ Once freed of the IкB subunit, the NF- $\kappa B$ proteins translocate to the nucleus, where they bind to target genes to activate gene expression ${ }^{175}$ (Fig. 3).

The NF- $\kappa B$ Inflammatory Mechanism. The aforementioned genes then code for a host of inflammatory molecules that include the following. 1) Proinflammatory cytokines (for example, IL-1 $\beta$, TNF $\alpha$, IL-6, and IL-18), which are involved in the initiation and amplification of the inflammatory process. ${ }^{27,43,119}$ 2) Protein kinases (mitogenactivated protein kinase and protein kinase $\mathrm{C}$ ) that regulate the expression of other target genes necessary for maintaining the inflammatory state. ${ }^{27,72,97} 3$ ) Various adhesion molecules, E-selectin, integrins, intracellular adhesion molecule-1, and vascular adhesion molecule- $1 .{ }^{16,27,44,72} 4$ ) Che-
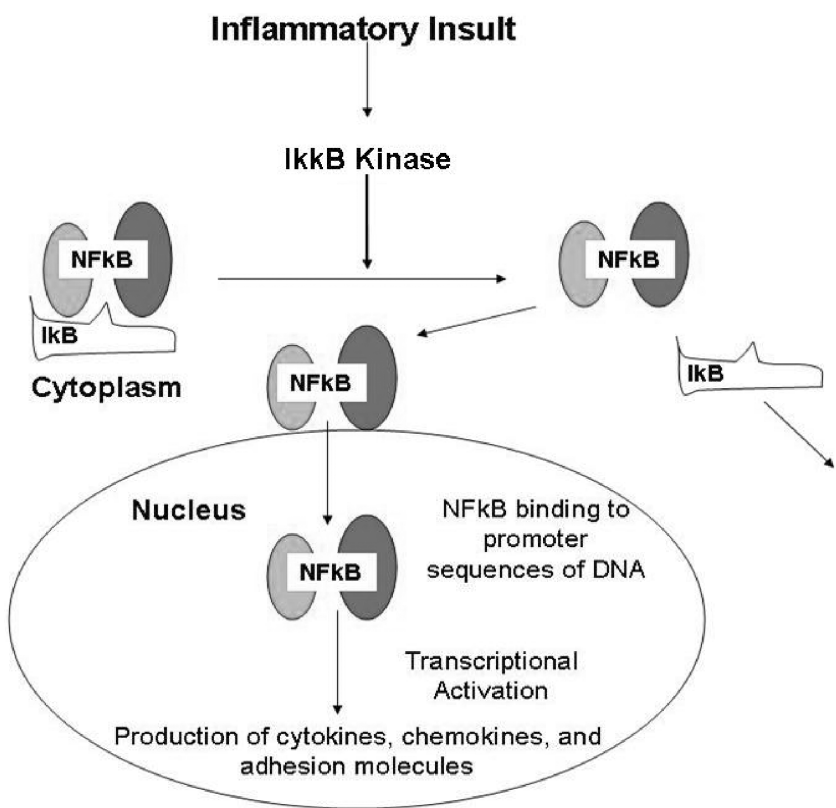

FIG. 3. Schematic showing another inflammatory pathway that is activated by tissue injury. This is the NF- $\mathrm{kB}$ activation, in which, once the protein is free as a result of tissue injury, it can enter the cell nucleus and activate the DNA to enhance the inflammatory response further by the production of additional cytokines, chemokines, and adhesion molecules. IKKB $=$ IкB kinase. 
mokines, a group of cytokines that chemically attract and activate leukocytes at the site of inflammation..$^{27,104,174} \mathrm{In}$ addition, activation of NF- $\kappa \mathrm{B}$ can enhance cell proliferation and cell growth, which can lead to neoplasia. ${ }^{15,27}$

The described pathway is believed to be just one of many diverse routes that are involved in activating the NF-кB pathway. Research into potential inhibitors that can prevent NF- $\kappa \mathrm{B}$ activation, and hence reduce the inflammatory process, will be the focus in elucidating the probable mechanism involved and developing the next blockbuster antiinflammatory medication. The identification of NF- $\kappa \mathrm{B}$ as a critical switch that turns on inflammation has profound implications for therapeutic manipulation of regulatory circuits controlling the inflammatory process, regardless of its causes. ${ }^{121}$

Inhibition of COX and $N F-\kappa B$ Activity. As stated earlier, the most commonly accepted mechanism to account for the inhibitory effects of most NSAIDs is that they inhibit COX activity to prevent prostaglandin synthesis. ${ }^{63,161}$ In recent reports, however, it has been suggested that additional mechanisms involving the NF- $\mathrm{kB}$ system are at work. Aspirin and sodium salicylate are now believed to target NF- $\mathrm{KB}$ as well as the COX system. These agents inhibit the NF-кB pathway in endothelial cells and block NF- $\kappa B$ activation to inhibit leukocyte recruitment. ${ }^{164-166}$ Other nonsteroidal agents have also been found to inhibit both the COX system and the NF- $\mathrm{BB}$ pathway. Immunosuppressant drugs also reduce nuclear expression of NF-кB. ${ }^{58,107,110,168,175}$

\section{Lesser-Known Side Effects of NSAIDs}

\section{Reduced Healing}

Besides the well-documented gastric side effects of NSAIDs and more recently discovered vascular side effects of selective COX-2 inhibitors, there are other less well-known but just as serious effects of NSAIDs, particularly in sports medicine. In this field of medicine, NSAIDs are still the most commonly used agent for the treatment of pain and inflammation arising from acute soft-tissue injuries, despite the wide recognition that there is no convincing evidence of their effectiveness in the treatment of these injuries. ${ }^{22}$ In fact, by blocking the COX1 or -2 inflammatory pathway, healing may actually be hampered. Various studies have shown that such agents delay muscle regeneration and that their primary role is actually in relieving pain, which could be done just as well with other medications without the deleterious effect of reduced healing. ${ }^{4,5}$ The use of NSAIDs has been shown to delay and hamper healing in all the soft tissues, including muscles (despite their tremendous blood supply), ligaments, tendons, and cartilage. ${ }^{4,5,83,111,123,127}$. Similarly, in animal studies corticosteroid agents have been shown to delay resolution of hematomas and are well known to delay healing.

The mechanism for this effect is as follows: by taking powerful NSAIDs, the patient does not permit the body to mount any-or at best a very limited-inflammatory response, which is generally believed to be necessary as a prelude to healing because it draws the white blood cells into the injured area to start the repair process. ${ }^{65} \mathrm{Spec}-$ ifically, NSAIDs are believed to wipe out the entire inflammatory proliferative phase of healing (Days 0-4). In Greene's study, ${ }^{65}$ at Day 2 there were essentially no macrophages (cells that clean up the site) in the injured area, and by Day 4 after the muscle strain, there was very little muscle regeneration compared with that seen in the normal healing process. In 1992, Greene showed in adult patients that muscle strength at this time was only approximately $40 \%$ of normal.

Although NSAIDs have commonly been used for the treatment of muscle injury, recent research has provided evidence that these drugs have limited effectiveness when it comes to such injuries. ${ }^{123}$ In an animal study, Rahusen, et al., ${ }^{132}$ obtained results that support this claim. These investigators evaluated the outcome after NSAIDs were used to treat acute muscle injury in 96 mice, and their findings agree with the statement Greene made earlier. In a study in which piroxicam was used on injured rabbits, researchers drew the same conclusion: NSAIDs did not help the healing process in muscle injuries. ${ }^{118} \mathrm{~A}$ study of the effects of NSAIDs on acute hamstring injuries was done in humans by Reynolds, et al., ${ }^{136}$ and these investigators concluded that patients who used NSAIDs did not experience a greater reduction of pain and soft-tissue swelling when compared with the placebo group. Interestingly enough, the authors noted that the NSAIDs group had worse pain associated with severe injuries compared with the placebo group. Furthermore, in several other studies investigators have actually noted a degradation of muscle tissue in patients treated with NSAIDs. Almekinders and Gilbert ${ }^{5}$ monitored the recovery of rats that received an injury in their tibialis anterior and were then treated with piroxicam. These researchers concluded that NSAIDs led to delayed recovery times and muscle growth. In yet another study in rats performed by Jarvinen, ${ }^{89}$ it was noted that NSAIDs caused muscles to weaken during the later stages of healing.

The NSAIDs have also been found to have negative effects on skeletal muscle tissue when given to mice before rigorous exercise. Hung, et al. ${ }^{85}$ found that mice given NSAIDs before engaging in exercise showed an increase in the levels of lactate dehydrogenase as well as production of lactic acid in the muscles. This is a cause for alarm because the increase in lactic acid and lactate dehydrogenase levels will lead to increased production of creatine kinase, and that indicates increased necrosis of muscle cells.

\section{Renal Side Effects in Athletes}

The NSAIDs are known to have adverse effects on kidney function. ${ }^{48,169}$ Situations resulting in stimulation of the renin-angiotensin system, such as dehydration or preexisting chronic renal failure or disease, may predispose athletes to acute renal failure through inhibition of prostaglandin synthesis, which can occur when taking NSAIDs. ${ }^{48,169}$ The relevance of this became very public in the world of professional basketball when two premier National Basketball Association players, Alonzo Mourning and Sean Elliot, suffered significant renal complications when taking large amounts of NSAIDs. ${ }^{173}$ While playing in the National Basketball Association, Mourning 
and Elliot often took NSAIDs daily to self-treat the pain and swelling associated with vigorous athletic activity. Both players suffered focal glomerulosclerosis and both subsequently required a kidney transplant. The National Kidney Foundation asserts that approximately $10 \%$ of kidney failures per year are directly correlated to substantial overuse of NSAIDs. Kenny Easley, an All-Pro safety of the Seattle Seahawks football team, claims that his kidney disease is closely related to the large amounts of NSAIDs he formerly ingested. Similar events have been reported in athletes competing in track and field at both the professional and amateur levels. In a recent study of high school football players, researchers have found that $75 \%$ of the players use NSAIDs, and $15 \%$ use them daily.

\section{Rediscovery of Alternative Antiinflammatory Agents}

Pain reduction through the use of pharmacologically derived antiinflammatory agents has been one of the greatest contributions of modern medicine. Despite the sophistication of drug design, however, major complications are still associated with virtually all medications used for pain reduction. On the other hand, plant-derived nutraceutical preparations have been used for hundreds and even thousands of years to obtain effective pain relief, and herbal medications are becoming increasingly popular because of their relatively few side effects. Nevertheless, there are problems associated with these dietary supplements, and their use requires knowledge of their biological action, clinical studies (both affirmative and negative), and potential interactions with other nutraceutical products and prescription medications. Their evaluation with appropriately designed controlled studies has exploded in recent years, and the findings must be viewed with a greater degree of confidence due to the study designs and quality of the investigators. The distribution of information on dietary supplements is often limited to media reports, and despite the quality of the studies, there is often limited information transferred to the medical community compared with studies of pharmacological discoveries, which are heavily reported by the pharmaceutical industry. It is important for healthcare practitioners to learn in a scientific and critical way about the various dietary supplements their patients are taking.

The processes used to prepare herb-derived compounds pose complications when it comes to determining the quantity and concentration of the products. ${ }^{46,96,149}$ The preparation processes are not standardized, and therefore the extraction process and the type of plant used may affect the true concentration of the product. In addition, there is a lack of uniformity within and between manufacturers. It can be difficult to determine which product and manufacturer offers the best consistency. Although standardization is unlikely, most products from major US manufacturers will be of a higher quality. Although in the US dietary supplements are not held to the same rigorous testing and standards as pharmaceutically derived medications, there are many regulations that still control their manufacture, because these are food products. The US government, through the FDA and other agencies, routinely inspects the manufacture of vitamins or supple- ments made in this country, as it would for any food product. $46,96,109,149$ Contaminants, such as the recently discovered high lead content found in various Ayurvedic preparations that were made by an Indian manufacturer and imported into the US, ${ }^{46,93,96,149}$ are generally thought to be uncommon, but can be a concern when purchasing imported supplements.

Because the FDA will not allow claims that vitamins or supplements can treat or cure a medical condition to be placed on the packages of dietary supplements, any claims must be vague and nonclinical, unless an FDA-approved trial has been completed. Due to the multibillion-dollar sales of nutraceutical products, and the desire of some manufacturers to inflate claims and perhaps not cite possible side effects, one must be cautious about various drug interactions, particularly bleeding complications associated with white willow bark, ginger, garlic, and others. Therefore, such medicinal preparations are not without risk. Many supplements, however, including those just listed, have been the subject of hundreds if not thousands of scientific reports and trials indicating both safety and efficacy. Supplements that can affect the inflammatory pathways are some of the most studied, and there are many reports substantiating their effectiveness. Because these are natural products, we believe they should be clear candidates as alternatives to pharmaceutical antiinflammatory agents in all patients, not just athletes. We have recently published a study in which omega-3 EFAs were used as an alternative and/or complementary agent to NSAIDs to treat spine-related pain successfully in our patient series, which also included both amateur and professional athletes. ${ }^{108}$ Capsaicin, oil of camphor, and other natural topical preparations are commonly used for muscle soreness and local application for painful traumatic injuries..$^{21,29,30,116}$ Additional scientific studies are needed to elucidate further the potential applications of natural agents in the treatment of traumatically induced pain syndromes. Nevertheless, with hundreds of studies now completed and very positive personal testimonials, there are now early indications that many natural supplements have a place in treating pain and its root cause, inflammation.

\section{Overview of Natural Antiinflammatory Agents}

Having given this abbreviated overview of the inflammatory process and the major complications of the most frequently prescribed antiinflammatory drugs, we now will discuss some of the more commonly used naturally occurring compounds derived from plants in their capacity as modulators of the COX, NF- $\mathrm{BB}$, and cytokine pathways to reduce inflammation and pain (Fig. 4).

Since ancient times our ancestors have used phytochemicals found in plants to curtail the inflammatory process. For example, the bark of the willow tree was used as an analgesic and antipyretic medication more than 2400 years ago by the Greeks and Romans. ${ }^{20}$ The discovery of aspirin in 1899 was based on this observation.

The emergence of today's pharmaceutical industry, in large part, has been based on natural products. Drugs such as digoxin, Taxol, artemisinin, and scores more have been developed from phytochemicals. ${ }^{80,138}$ Not only have many medical breakthroughs been based on compounds of natural origin, but these also represent a large share of the 


\section{Alternative Therapy for Inflammation}

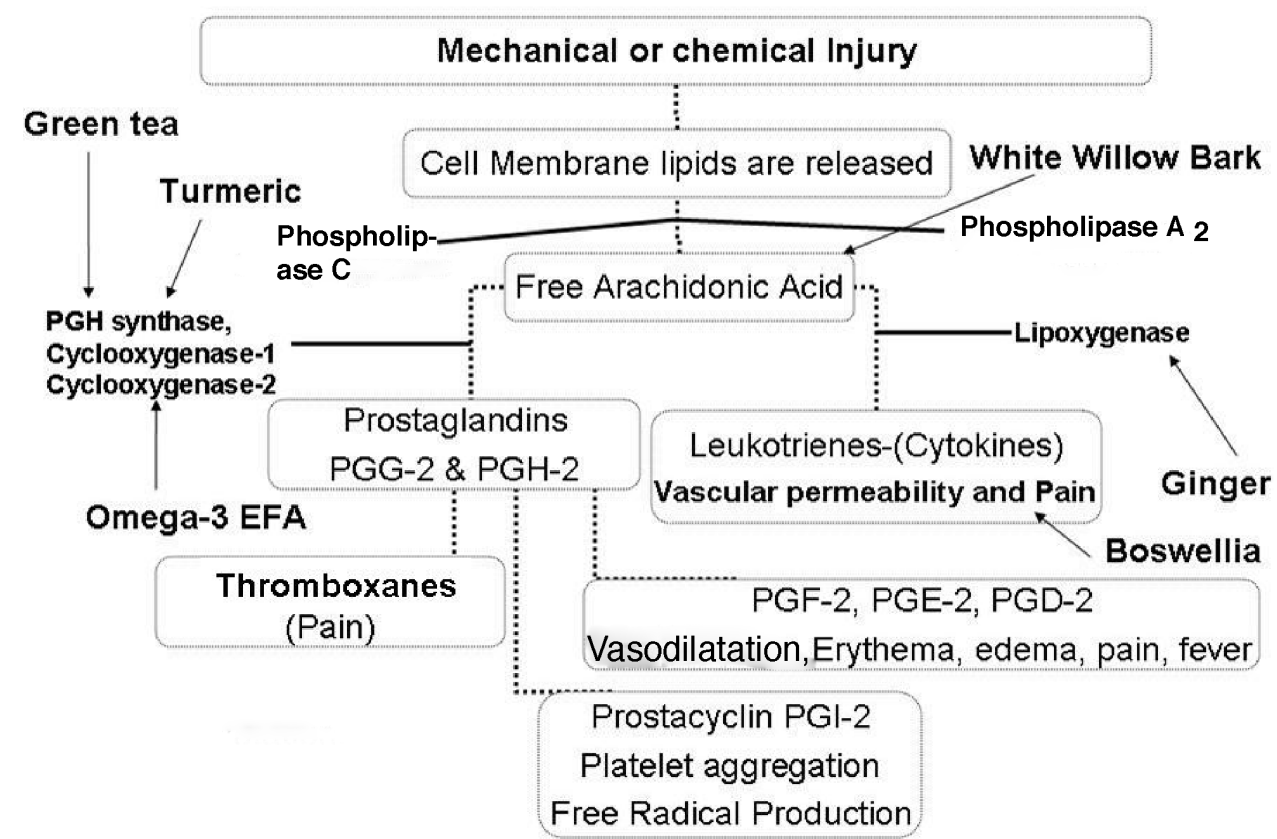

FIG. 4. Schematic showing the inflammatory pathway, starting with tissue injury and ending with the inflammatory prostaglandins, thromboxanes, and leukotrienes. The natural antiinflammatory agents omega-3 EFA, white willow bark, turmeric (curcumin), green tea, and Boswellia have all been shown to have various abilities to block certain parts of this pathway. Pycnogenol, cat's claw, and capsaicin also have antiinflammatory effects associated with their action on the NF- $\kappa$ B pathway. PGD-2 = prostaglandin D2; PGG = prostaglandin $\mathrm{G} ; \mathrm{PGH}=$ prostaglandin $\mathrm{H}$.

drug market. In 1999, close to $50 \%$ of the 20 best-selling drugs were derived from natural products, and their sales amounted to approximately $\$ 16$ billion..$^{80,92}$ According to a survey by the National Cancer Institute, $61 \%$ of the 877 small molecules, which are new chemical entities introduced as drugs worldwide from 1981 to 2002, were inspired by natural products. The following is a discussion of the most commonly used natural antiinflammatory agents and their mechanism of action.

\section{Omega-3 EFAs (Fish Oil)}

The use of fish oil (in the form of cod liver oil), an omega-3 EFA, for the treatment of muscular, skeletal, and discogenic diseases can be traced back to the late 18th century. As detailed by Curtis, et al., ${ }^{37}$ Dr. Thomas Percival recommended 1 to 3 tablespoons of cod liver oil two to four times per day for the treatment of "obstinate chronic rheumatisms, sciaticas of long standing, and in those cases of premature decrepitude, which originate from immoderate labor, repeated strains and bruises, or exposure to continuous dampness and cold; by which the muscles and tendons become too rigid, and the flexibility of the joints is impaired, so as to crackle for want of a due secretion of synovia." Unfortunately, because of the rapid onset of rancidity of this polyunsaturated oil when exposed to air and hence its disconcerting odor, cod liver oil fell out of favor.

With recently developed extraction techniques, which are performed under a nitrogen blanket, and with enhanced oxygen-free encapsulation methods, which prevent oxidation, the therapeutic benefits of fish oil can now be realized without the regurgitation and odor of previous products. Research has shown that the omega-3 polyunsaturated fatty acids are some of the most effective natural antiinflammatory agents available. . $6,37-39,108,124$ With the discovery that vascular inflammation is the underlying cause of coronary artery disease, fish and fish oil supplements are now recommended by the American Heart Association for the prevention of this disease. ${ }^{40,124}$ Countries in which the highest fish consumption occurs have populations with a lower incidence of neurodegenerative disease and depression..$^{74,78,108,171}$ The biological basis for the effectiveness of fish oil in treating arthritis has been well documented, with many positive clinical studies when compared with traditional pharmaceutical antiinflammatory agents. ${ }^{37,163}$

The active ingredients in fish oil, EPA and DHA, enhance the conversion of COX to prostaglandin E3.26,37,108 A natural antiinflammatory agent, prostaglandin E3 competitively inhibits the effects of the arachidonic acid conversion to prostaglandin E2, a highly inflammatory substance. Prostaglandin E3 also inhibits the synthesis of TNF $\alpha$ and IL-1 $\beta$, both of which are inflammatory cytokines. The EPA and DHA can inhibit the 5-LOX pathway, which converts arachidonic acid to inflammatory leukotrienes, also by competitive inhibition. When EPA and DHA are incorporated into articular cartridge chondrocyte cell membranes, there is a dose-dependent decrease in the expression and activity of the proteoglycan-degrading aggrecanase enzymes. ${ }^{26,37-39,108}$

Omega-3 EFA, found in fish oil, can directly reduce the degenerative enzymes aggrecanase and matrix metalloproteinase, as well as IL-1, TNF $\alpha$, and COX-2 to reduce 
the inflammation in synovial cartilage ${ }^{38} \mathrm{~A}$ recent study of 250 patients with cervical and lumbar disc disease who were taking NSAIDs revealed that $59 \%$ could substitute fish oil supplements as a natural antiinflammatory agent for the NSAIDs. ${ }^{108}$ The recommended dosage is a total of 1.5 to $5 \mathrm{~g}$ of EPA and DHA per day, taken with meals. ${ }^{38}$ Rare side effects include steatorrhea and occasional belching if the supplements are not taken with meals. Typically, persons on a regimen of anticoagulant medications should not take omega-3 EFAs because of the possibility of increasing the bleeding potential.

\section{White Willow Bark}

Bark from the white willow tree is one of the oldest herbal remedies for pain and inflammation. It has been used by the ancient Egyptian, Roman, Greek, and Indian civilizations as an analgesic and antipyretic agent. ${ }^{149}$ In fact, the first record of its use is found in the Ebers papyrus, written more than 3500 years ago. Because the drug caused gastric irritation, the French chemist Charles Gerhardt neutralized salicylic acid and created acetylsalicylic acid. ${ }^{76,149}$ In 1897, Felix Hoffmann used the agent to treat his father's rheumatoid arthritis, and because of his success, the Bayer Corporation marketed the product under the trade name of aspirin, which is now one of the most widely prescribed nutraceutical agents in the world.

Because of the side effects of aspirin, there has been a resurgence in the use of white willow bark for the treatment of inflammatory syndromes. ${ }^{149}$ Salix alba, or white willow, is the species most commonly used for medicinal purposes. The mechanism of action of white willow bark is similar to that of aspirin in that it is also a nonselective inhibitor of COX-1 and COX-2, thus reducing the inflammatory prostaglandins. ${ }^{94}$ Various randomized placebocontrolled studies comparing white willow bark with nonsteroidal agents have show an efficacy comparable to these agents and aspirin. ${ }^{20,32,33,51,60,98,106,145,146,149}$ Salicin from white willow bark is converted to salicylic acid by the liver and is considered to have fewer side effects than aspirin. ${ }^{20,94}$ However, it is more costly than aspirin, and should not be used in children (to avoid the risk of Reye syndrome), or in patients with peptic ulcer disease, diabetes, hepatic or renal disorders, or other conditions in which aspirin would be contraindicated. The usual dose of white willow bark is $240 \mathrm{mg}$ per day.

\section{Curcumin (Turmeric)}

Curcumin is a naturally occurring yellow pigment derived from turmeric (Curcuma longa), a flowering plant in the ginger family. ${ }^{10}$ It has traditionally been used as a coloring and flavoring spice in food products. ${ }^{19,115}$ Curcumin has long been used in both Ayurvedic and Chinese medicine as an antiinflammatory agent, a treatment for digestive disorders, and to enhance wound healing. Several clinical trials have demonstrated curcumin's antioxidant, antiinflammatory, and antineoplastic effects. ${ }^{10,35,115,160}$ In a recent article in the New England Journal of Medicine, Zandi and Karin ${ }^{177}$ suggested that curcumin might be efficacious in the treatment of cystic fibrosis because of its antiinflammatory effect. Curcumin is known to inhibit inflammation by suppressing NF- $\kappa \mathrm{B},{ }^{64}$ restricting various activators of NF- $\mathrm{KB}$ as well as stemming its expres- sion. ${ }^{18,64,126}$ Curcumin has been suggested as a treatment for colitis, chronic neurodegenerative diseases, arthritis, and cancer. ${ }^{18,19,63,126}$ In addition, it regulates the activity of several enzymes and cytokines by inhibiting both COX-1 and-2. ${ }^{86}$ Most studies to date have been performed in animals, ${ }^{13,19}$ but given the centuries of use of curcumin, as well as its now demonstrated activity in the NF- $\mathrm{KB}, \mathrm{COX}-1$, and COX-2 inflammatory pathways, it may be considered a viable natural alternative to nonsteroidal agents for the treatment of inflammation.

The usual dosage of standardized turmeric powder is 400 to $600 \mathrm{mg}$ taken three times per day. ${ }^{19}$ Side effects are few, but with extended use this agent can cause stomach upset, and in extreme cases gastric ulcers may occur at very high doses. Caution should be used if the patient is taking anticoagulant medications or high doses of nonsteroidal drugs. Studies have shown that curcumin may be used in combination with lower doses of nonsteroidal medications..$^{59}$ Curcumin's therapeutic effects are considered comparable to pharmaceutical nonsteroidal medications such as phenylbutazone, but with a major difference in that this compound is relatively nontoxic and free of side effects. ${ }^{11,18,19,64,126}$

\section{Green Tea}

Green tea has long been recognized to have cardiovascular and cancer preventative characteristics due to its antioxidant properties. ${ }^{37}$ Its use in the treatment of arthritic disease as an antiinflammatory agent has been recognized more recently. The constituents of green tea are polyphenolic compounds called catechins, and epigallocatechin-3 galate is the most abundant catechin in green tea. ${ }^{37,73,81,161,176}$

Epigallocatechin-3 galate inhibits IL-1-induced proteoglycan release and Type 2 collagen degradation in cartilage explants. ${ }^{2,37}$ In human in vitro models, it also suppresses IL- $1 \beta$ and attenuates activation of the transcription factor NF-кB. ${ }^{155}$ Green tea also inhibits the aggrecanases, which degrade cartilage. ${ }^{167}$

From various studies, the molecular basis of the antiinflammatory and chondroprotective effects of green tea is being discovered. A recent review article from Yale University regarding green tea as the Asian paradox summarizes its currently recognized therapeutic effects: as a cardiovascular and neuroprotective agent, an inhibitor of carcinogenesis, and an antiinflammatory agent. ${ }^{158}$ The usual recommendation is 3 to 4 cups of tea a day. If the patient is taking green tea extract, a dosage of 300 to 400 $\mathrm{mg}$ is typical. Green tea can cause stomach irritation in some, and because of its high caffeine content, a decaffeinated variety should be considered

\section{Pycnogenol (Maritime Pine Bark)}

Pycnogenol, like white willow bark, is a nutraceutical material that has been used since ancient times. Pycnogenol is derived from the bark of the maritime pine tree (Pinus maritima) and has been used for more than 2000 years. ${ }^{31,101,120}$ Hippocrates mentions its use as an antiinflammatory agent. It has been considered helpful for wound healing, treating scurvy, healing of ulcers, and reducing vascular inflammation. It contains a potent blend of active polyphenols that includes catechin, taxifolin, 
procyanidins, and phenolic acids. It is one of the most potent antioxidant compounds currently known. ${ }^{120}$ Pycnogenol inhibits TNF $\alpha$-induced NF- $\mathrm{BB}$ activation as well as adhesion molecule expression in the endothelium. ${ }^{123}$ Grimm and colleagues ${ }^{67,68}$ recently reported that oral intake of pycnogenol inhibited NF-кB activation in lipopolysaccharide-stimulated monocytes as well, thus decreasing the inflammatory response. It also statistically significantly inhibited matrix metalloproteinase-9. ${ }^{67-69}$ This matrix-degrading enzyme is highly expressed at sites of inflammation, and contributes to the pathogenesis of various chronic inflammatory diseases.

In a recently published review article on pycnogenol and its effect on the cardiovascular system, investigators concluded that due to its antiinflammatory activity, this agent has the potential to counteract major cardiovascular risk factors, including reducing platelet activity and reducing the inflammatory process that underlies coronary artery disease. ${ }^{9,131}$ With the mounting evidence of its antiinflammatory effects and its virtual absence of toxicity, pycnogenol may play a larger role in the treatment of the pain from arthritic conditions in athletes as well as in degenerative disease of all kinds. ${ }^{122}$ Due to its potent antioxidant effects, enhancement of sports endurance was indicated in a recent study in which athletes took $200 \mathrm{mg}$ per day of pycnogenol. Vigorous sports activity dramatically increases oxygen consumption, by 10 - to 20 -fold over the resting state. Hence, an increased number of free radicals is generated during exhaustive exercise. Pycnogenol is thought to counteract the deleterious effects of these free radicals and improve blood flow to muscle, as was demonstrated by Pavlovic ${ }^{122}$ in a double-blind cross-over study of 24 recreational athletes.

Studies have shown that this agent is 50 to 100 times more potent than vitamin $\mathrm{E}$ in neutralizing free radicals and that it helps recycle and prolong the activity of vitamins $\mathrm{C}$ and E. ${ }^{117,120}$ Studies have shown pycnogenol to be effective in reducing blood pressure and reducing the risk of venous thrombosis by its effect on vascular endothelium. ${ }^{17,54,83,103}$ The usual dosage is 100 to $200 \mathrm{mg}$ daily. Few side effects from the use of pine bark extracts have been reported, the most frequent being mild gastrointestinal effects such as diarrhea and upset stomach. ${ }^{102,103}$ Pycnogenol should not be taken by patients who are being treated with immunosuppressants or by those receiving corticosteroid drugs, because it can enhance immune system function and interact with drugs that are supposed to suppress the immune system. ${ }^{3,102,103}$

\section{Boswellia serrata Resin (Frankincense)}

The Boswellia species are trees located in India, Ethiopia, Somalia, and the Arabian peninsula that produce a gum resin called olibanum, better known in the western world as frankincense. ${ }^{1,14}$ This resin possesses antiinflammatory, antiarthritic, and analgesic properties. ${ }^{95}$ It is known to inhibit the leukotriene biosynthesis in neutrophilic granulocytes by inhibiting 5-LOX. Various inflammatory diseases are perpetuated by leukotrienes, hence some of the antiinflammatory activity of this agent. ${ }^{14,61,70,71,84,139,140,142,147}$ Clinically, the substance is used in the treatment of degenerative and inflammatory joint disorders. It reduces the total white blood cell count in joint fluid, ${ }^{95,99}$ and it also inhibits leukocyte elastase, which

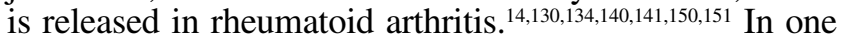
recent study, a statistically significant improvement in arthritis of the knee was shown after 8 weeks of treatment with $333 \mathrm{mg} \mathrm{B}$. serrata extract taken three times a day. The treatment improved function, but radiographically there was no change in the affected joints..$^{95}$ Another study by Kulkarni, et al., ${ }^{99}$ demonstrated a significant drop in pain severity and disability. A combination of Boswellia and curcumin showed superior efficacy and tolerability compared with nonsteroidal diclofenac for treating active osteoarthritis. Boswellia typically is given as an extract standardized to contain 30 to $40 \%$ boswellic acids (300$500 \mathrm{mg}$ two or three times/day). Boswellia has been well tolerated in most studies, although some people may experience stomach discomfort, including nausea, acid reflux, or diarrhea. ${ }^{6,95}$

\section{Uncaria tomentosa (Cat's Claw)}

Uncaria tomentosa $a^{8,137}$ and $U$. guianensis ${ }^{100}$ are Peruvian herbs derived from woody vines with small clawlike thorns (hence the vernacular name, cat's claw) at the base of the leaf that allows the plant to climb to heights of up to $100 \mathrm{ft} .{ }^{56,57,149}$ Traditionally, a decoction of the bark of the cat's claw is used to treat arthritis, bursitis, and intestinal disorders. ${ }^{56,57,125,149,152,153}$ The active ingredients appear to be polyphenols (flavonoids, proanthocyanidins, an tannins), alkaloids, and sterols.,143,149 Various studies indicate that this Peruvian herb induces a generalized reduction in proinflammatory mediators. ${ }^{3,111,143,144,149,157}$

This herb has been shown to prevent the activation of the transcriptional factor NF- $\mathrm{B}^{64,144,149}$ and it directly inhibits TNF $\alpha$ production by up to 65 to $85 \% .{ }^{143}$ It inhibits the expression of inducible genes associated with inflammation, specifically negating the expression of inducible nitric oxide synthase, and hence attenuates nitrous oxide production. ${ }^{14}$ Side effects may include nausea, although it has shown an impressive protective effect on indomethacin-induced enteritis in laboratory studies. Although toxicity and side effects are usually minimal, two case reports of acute renal failure in a patient with lupus erythematosus have been recorded. ${ }^{79,90}$ Cat's claw can be consumed as a tea (1000 mg root bark to $8 \mathrm{oz}$ water), or as a dry, standardized extract in a capsule (20-60 mg daily). ${ }^{149}$

\section{Capsaicin (Chili Pepper)}

Capsicum annum is a small spreading shrub originally cultivated in the tropical regions of the Americas but now is grown throughout the world, including the US..$^{42}$ The small red fruit commonly used to accentuate chili owes its stinging pungency to the chemical capsaicin. This was isolated by chemists more than a century ago and constitutes approximately $12 \%$ of the chili pepper. This fruit has been used for medicinal purposes by the native peoples of the American tropics for hundreds of years.

More recently, various preparations have become available over the counter for the treatment of peripheral neuropathies and chronic musculoskeletal pain. Capsaicin produces highly selective regional anesthesia by causing degeneration of capsaicin-sensitive nociceptive nerve endings, which can produce significant and long-lasting increases in nociceptive thresholds. ${ }^{28,34,53,87,88,128}$ Capsaicin 
potently activates transient receptor potential vanilloid 1 , which is a main receptor underlying nociception. ${ }^{82,91,128,159}$ It also inhibits NF- $\kappa \mathrm{B}$, thus producing an antiinflammatory effect. ${ }^{64}$ Capsaicin can cause a burning sensation when it comes in contact with human flesh, and also in the digestive tract. This herb is rarely used alone but is generally mixed into other natural antiarthritic preparations. ${ }^{60}$ There are topical capsaicin formulations now available to treat postherpetic neuralgia.

\section{Conclusions}

Traumatic musculoskeletal and discogenic injuries are commonly associated with sports participation. Inflammation with pain, swelling, and erythema is the body's natural response to injury. In an attempt to reduce pain and swelling, athletes often use antiinflammatory agents that act on the arachidonic acid/COX and the NF- $\mathrm{B}$ pathways mediating inflammation. Unfortunately, pharmacological agents designed to interfere with these pathways often have undesirable side effects such as gastric ulceration and, infrequently, myocardial infarction and stroke.

For centuries, natural antiinflammatory agents have been used to mediate the inflammatory process. More recently, many of these have been found to reduce inflammation in a similar manner to pharmacological agents but often with fewer side effects. We have briefly reviewed the pharmacology of several plant-derived natural drugs that could reduce costs and side effects in patients who use them, with similar effectiveness in treating the inflammatory reaction to trauma. Ongoing experiments and clinical trials for several of these medications are needed, and we hope such trials will provide the scientific basis for the effectiveness of agents that have been used empirically for centuries to reduce inflammation.

\section{References}

1. Acebo E, Raton JA, Sautua S, Eizaguirre X, Trébol I, Pérez JLD: Allergic contact dermatitis from Boswellia serrata extract in a naturopathic cream. Am J Contact Dermat 51:91-92, 2004

2. Adcocks C, Collin P, Buttle DJ: Catechins from green tea (Camellia sinensis) inhibit bovine and human cartilage proteoglycan and type II collagen degradation in vitro. J Nutr 132: 341-346, 2002

3. Aguilar JL, Rojas P, Marcelo A, Plaza A, Bauer R, Reininger E, et al: Anti-inflammatory activity of two different extracts of Uncaria tomentosa (Rubiaceae). J Ethnopharmacol 81: 271-276, 2002

4. Almekinders LC: Anti-inflammatory treatment of muscular injuries in sport. An update of recent studies. Sports Med 28: 383-388, 1999

5. Almekinders LC, Gilbert JA: Healing of experimental muscle strains and the effects of nonsteroidal anti-inflammatory medication. Am J Sports Med 14:303-308, 1986

6. Anonymous: Boswellia serrata. Altern Med Rev 3:306-307, 1998

7. Anonymous: Celebrex Prescriptions Plunge After Risk Found. New York: Reuters, December 30, 2004

8. Aquino R, De Feo V, De Simone F, Pizza C, Cirino G: New compounds and anti-inflammatory activity of Uncaria tomentosa. J Nat Prod 54:453-459, 1991

9. Araghi-Niknam M, Hosseini S, Larson D, Rohdewald P, Watson RR: Pine bark extract reduces platelet aggregation. Integr Med 2:73-77, 2000
10. Araujo CC, Leon LL: Biological activities of Curcuma longa L. Mem Inst Osawaldo Cruz 96:723-728, 2001

11. Badria FA, El-Farahaty T, Shabana AA, Hawas SA, El-Batoty MF: Boswellia-curcumin preparation for treating knee osteoarthritis: a clinical evaluation. Alt Complement Ther 8: 341-348, 2002

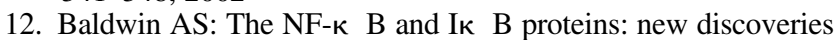
and insights. Annu Rev Immunol 14:649-681, 1996

13. Banerjee M, Tripathi LM, Srivastava VM, Puri A, Shukla R: Modulation of inflammatory mediators by ibuprofen and curcumin treatment during chronic inflammation in rat. Immunopharmacol Immunotoxicol 25:213-224, 2003

14. Banno N, Akihisa T, Yasukawa K, Tokuda H, Tabata K, Nakamura Y, et al: Anti-inflammatory activities of the triterpene acids from the resin of Boswellia carteri. J Ethnopharmacol 107:249-253, 2006

15. Barkett M, Gilmore TD: Control of apoptosis by Rel/NF-к B transcription factors. Oncogene 18:6910-6924, 1999

16. Barnes PJ, Karin M: Nuclear factor- $\kappa$ B. A pivotal transcription factor in chronic inflammatory diseases. N Engl J Med 336:1006-1071, 1997

17. Belcaro G, Cesarone MR, Rohdewald P, Ricci A, Ippolito E, Dugall M, et al: Prevention of venous thrombophlebitis in longhaul flights with pycnogenol. Clin Appl Thromb Hemost 10: 373-377, 2004

18. Bengmark S: Curcumin, an atoxic antioxidant and natural NFK $\mathrm{B}$, cyclooxygenase-2, lipooxygenase, and inducible nitric oxide synthase inhibitor: a shield against acute and chronic diseases. JPEN J Parenter Enteral Nutr 30:45-51, 2006

19. Berman B (ed): Turmeric. Baltimore: University of Maryland Medical Center 2004. (http://www.umm.edu/altmed/Cons Herbs/Turmericch.html) [Accessed 13 September 2006]

20. Berman B (ed): Willow Bark. Baltimore: University of Maryland Medical Center 2004. (http://www.umm.edu/altmed/Cons Herbs/WillowBarkch.html) [Accessed 13 September 2006]

21. Bernstein JE, Bickers DR, Dahl MV, Roshal JY: Treatment of chronic postherpetic neuralgia with topical capsaicin. A preliminary study. J Am Acad Dermatol 17:93-98, 1987

22. Blumenthal M, Riggins C: Popular Herbs in the U.S. Market. Therapeutic Monographs. Austin, Texas: The American Botanical Council, 1997

23. Boyles S: Vioxx, Celebrex were overused, study shows, $3 / 4$ of users had little need for Cox-2 inhibitors. WebMD Medical News 2005 (http://www.webmd.com/content/article/99/ 105308.htm) [Accessed 13 September 2006]

24. Bruckner P: Clinical Sports Medicine. New York: McGrawHill, 1995, pp 56-60

25. Burton TM: Monsanto arthritis-pain drug, Celebrex, surpasses Viagra's early sales success. The Wall Street Journal B: 6 , 1999

26. Calder PC: n-3 Polyunsaturated fatty acids, inflammation, and inflammatory diseases. Am J Clin Nutr 83(6 Suppl):1505S1519S, 2006

27. Calixto JB, Campos MM, Otuki MF, Santos ARS: Anti-inflammatory compounds of plant origin. Part II: modulation of proinflammatory cytokines, chemokines and adhesion molecules. Planta Med 70:93-103, 2004

28. Caterina MJ, Julius D: The vanilloid receptor: a molecular gateway to the pain pathway. Annu Rev Neurosci 24:487-517, 2001

29. Caterina MJ, Leffler A, Malmberg AB, Martin WJ, Trafton J, Petersen-Zeitz KR, et al: Impaired nociception and pain sensation in mice lacking the capsaicin receptor. Science 288:306-313, 2000

30. Caterina MJ, Schumacher MA, Tominaga M, Rosen TA, Levine JD, Julius D: The capsaicin receptor: a heat-activated ion channel in the pain pathway. Nature 389:816-824, 1997

31. Cho KJ, Yun CH, Yoon DY, Cho YS, Rimbach G, Packer L: Effects of bioflavonoids extracted from the bark of Pinus mar- 
itime on proinflammatory cytokine interleukin-1 production in lipopoysaccharide-stimulated RAW 264.7. Toxicol Appl Pharmacol 168:64-71, 2000

32. Chrubasik S, Eisenberg E, Balan E, Weinberger T, Luzzati R, Conradt C: Treatment of low back pain exacerbations with willow bark extract: a randomized double blind study. Am J Med 9:9-14, 2000

33. Chrubasik S, Künzel O, Model A, Conradt C, Black A: Treatment of low back pain with a herbal or synthetic anti-rheumatic: a randomized controlled study. Willow bark extract for low back pain. Rheumatology 40:1388-1393, 2001

34. Chung JM, Lee KH, Hori Y, Willis WD: Effects of capsaicin applied to a peripheral nerve on the responses of primate spinothalamic tract cells. Brain Res 329:27-38, 1985

35. Claeson P, Panthong A, Tuchinda P, Reutrakul V, Kanjanapothi $\mathrm{D}$, Taylor WC, et al: Three non-phenolic diarylheptanoids with anti-inflammatory activity from Curcuma xanthorrhiza. Planta Med 59:451-454, 1993

36. Clemett D, Goa KL: Celecoxib: a review of its use in osteoarthritis, rheumatoid arthritis and acute pain. Drugs 59: 957-980, 2000

37. Curtis CL, Harwood JL, Dent CM, Caterson B: Biological basis for the benefit of nutraceutical supplementation in arthritis. Drug Discov Today 9:165-172, 2004

38. Curtis CL, Hughes CE, Flannery CR, Little CB, Harwood JL, Caterson B: n-3 fatty acids specifically modulate catabolic factors involved in articular cartilage degradation. J Bio Chem 275:721-724, 2000

39. Curtis CL, Rees SG, Little CB, Flannery CR, Hughes CE, Wilson $\mathrm{C}$, et al: Pathologic indicators of degradation and inflammation in human osteoarthritic cartilage are abrogated by exposure to n-3 fatty acids. Arthritis Rheum 46:1544-1553, 2002

40. Daviglus ML, Stamler J, Orencia AJ, Dyer AR, Liu K, Greenland $\mathrm{P}$, et al: Fish consumption and the 30-year risk of fatal myocardial infarction. N Engl J Med 336:1046-1053, 1997

41. Davis JL: Vioxx estimate: up to 140,000 got heart disease, arthritis drug doubled risk of serious heart problems, heart attacks. WebMD Medical News 2005. (http://aolsvc.health. webmd.aol.com/content/article/99/105333.htm) [Accessed 14 September 2006]

42. Dickson C: Cayenne: the Burning Balm. (http://www.ulew. com/cayenne.php) [Accessed 14 September 2006]

43. Dinarello CA: Proinflammatory cytokines. Chest 118: 503-508, 2000

44. Donaldson LF, Hanley MR, Villablanca AC: Inducible receptors. Trends Pharmacol Sci 18:171-181, 1997

45. Ehrich EW, Dallob A, De Lepeleire I, Van Hecken A, Riendeau $D$, Yuan W, et al: Characterization of rofecoxib as a cyclooxygenase-2 isoform inhibitor and demonstration of analgesia in the dental pain model. Clin Pharmacol Ther 65:336-347, 1999

46. Ernst E: Adulteration of Chinese herbal medicines with synthetic drugs: a systematic review. J Intern Med 252:107-113, 2002

47. Fagan T: Safety concerns halt ADAPT trial. Alzheimer Research Forum. (http://www.alzforum.org/new/detail.asp? id=1130) [Accessed 14 September 2006]

48. Farquhar B, Kenney WL: Anti-inflammatory drugs, kidney function, and exercise. SSE \#67 11: Article 4, 1997

49. Fennerty MB: NSAID-related gastrointestinal injury: evidencebased approach to a preventable complication. Postgrad Med 110:87-94, 2001

50. Fernández-Celemín L, Pasko N, Blomart V, Thissen JP: Inhibition of muscle insulin-like growth factor I expression by tumor necrosis factor- $\alpha$. Am J Physiol Endocrinol Metab 283:E1279-E1290, 2002

51. Fiebich BL, Chrubasik S: Effects of an ethanolic Salix extract on the release of selected inflammatory mediators in vitro. Phytomedicine 11:135-138, 2004

52. Fitzgerald GA: Coxibs and cardiovascular disease. N Engl J Med 351:1709-1711, 2004
53. Fitzgerald M, Woolf CJ: The time course and specificity of the changes in the behavioral and dorsal horn cell responses to noxious stimuli following peripheral nerve capsaicin treatment in the rat. Neuroscience 7:2051-2056, 1982

54. Fitzpatrick DF, Bing B, Rohdewald P: Endothelium-dependent vascular effects of Pycnogenol. J Cardiovasc Pharmacol 32:509-515, 1998

55. Fosslien E: Cardiovascular complications of non-steroidal antiinflammatory drugs. Ann Clin Lab Sci 35:347-385, 2005

56. Foster S: Herbs For Your Health. Loveland, CO: Interweave Press, 1996

57. Foster S, Tyler VE: Tyler's Honest Herbal: A Sensible Guid to the Use of Herbs and Related Remedies, ed 4. New York: The Haworth Press, 1999, pp 97-99

58. Frantz B, Nordby EC, Bren G, Steffan N, Paya CV, Kincaid $\mathrm{RL}$, et al: Calcineurin acts in synergy with PMA to inactivate I kappa B/MAD3, an inhibitor of NF-к B. Embo J 13:861-870, 1994

59. Funk JL, Oyarzo JN, Frye JB, Chen G, Lantz RC, Jolad SD, et al: Turmeric extracts containing curcuminoids prevent experimental rheumatoid arthritis. J Nat Prod 69:351-355, 2006

60. Gagnier JJ, vanTulder M, Berman B, Bombardier C: Herbal medicine for low back pain. Cochrane Database Syst Rev: CD004504, 2006

61. Gerhardt H, Seifert F, Buvari P, Vogelsang H, Repges R: Therapy of active Crohn disease with Boswellia serrata extract $\mathrm{H}$ 15. Z Gastroenterol 39:11-17, 2001

62. Ghosh S, May MJ, and Kopp EB: NF-к B and Rel proteins: evolutionarily conserved mediators of immune responses. Annu Rev Immunol 16:225-260, 1998

63. Gilroy DW, Colville-Nash PR, Willis D, Chivers J, Paul-Clark MJ, Willoughby DA: Inducible cyclooxygenase may have antiinflammatory properties. Nat Med 5:698-701, 1999

64. Goepp JG: What is nuclear factor-kappa beta? Life Extension Magazine, July 2006. (http: //www.lef.org/magazine/mag 2006/jul2006_report_nuclear_01.htm\#AnchorFusion) [Accessed 27 September, 2006]

5. Greene J: Cost-conscious prescribing of nonsteroidal anti-inflammatory drugs for adults with arthritis. A review and suggestions. Arch Intern Med 152:1995-2002, 1992

66. Griffin MR: The COX-2 report: the good, the bad and the unknown. JCOM 7:62-66, 2000

67. Grimm T, Chovanová Z, Muchová J, Sumegová K, Liptáková A, Durackova Z, et al: Inhibition of NF- $\mathrm{B}$ activation and MMP-9 secretion by plasma of human volunteers after ingestion of maritime pine bark extract (Pycnogenol). J Inflamm 3: 1,2006

68. Grimm T, Schäfer A, Högger P: Antioxidant activity and inhibition of matrix metalloproteinasas by metabolites of maritime pine bark extract (Pycnogenol). Free Radic Biol Med 36: 811-822, 2004

69. Gulati OP: Pycnogenol in venous disorders: a review. Eur Bull Drug Res 7:8-13, 1999

70. Gupta I, Gupta V, Parihar A, Gupta S, Ludtke R, Safayhi H, et al: Effects of Boswellia serrata gum resin in patients with bronchial asthma: results of a double-blind, placebo-controlled, 6-week clinical study. Eur J Med Res 3:511-514, 1998

71. Gupta I, Parihar A, Malhotra P, Gupta S, Ludtke R, Safayhi H, et al: Effects of gum resin of Boswellia serrata in patients with chronic colitis. Planta Med 67:391-395, 2001

72. Haddad JJ: Cytokines and related receptor-mediated signaling pathways. Biochem Biophys Res Comm 297:700-713, 2002

73. Haqqi TM, Anthony DD, Gupta S, Ahmad N, Lee MS, Kumar GK, et al: Prevention of collagen-induced arthritis in mice by a polyphenolic fraction from green tea. Proc Natl Acad Sci U S A 96:4524-4529, 1999

74. Harris WS, von Schacky C: The Omega-3 Index: a new risk factor for death from coronary heart disease? Prev Med 39: 212-220, 2004 
75. Hawkey CJ: COX-2 inhibitors. Lancet 353:307-314, 1999

76. Hedner T, Everts B: The early clinical history of salicylates in rheumatology and pain. Clin Rheumatol 17:17-25, 1998

77. Hegmann T: A tale of two coxibs. JAAPA 18:14-17, 2005

78. Higdon J: Essential Fatty Acids. Linus Pauling Institute at Oregon State University (http://lpi.oregonstate.edu/infocenter/ othernuts/omega3fa/index.html) [Accessed 14 September 2006]

79. Hilepo JN, Bellucci, Mossey RT: Acute renal failure caused by "cat's claw" herbal remedy in a patient with systemic lupus erythematosus. Nephron 77:361, 1997

80. Hitti M: Timeline of pain reliever controversy, tracing the path on Cox-2, NSAID pain relievers. WebMD Medical News, April 7, 2005. (http: //www.webmd.com/content/article/104/ 107304.htm) [Accessed 27 September, 2006]

81. Hollman PC, Feskens EJ, Katan MB: Tea flavonols in cardiovascular disease and cancer epidemiology. Proc Soc Exp Biol Med 220: 198-202, 1999

82. Holzer P: Capsaicin: cellular targets, mechanisms of action, and selectivity for thin sensory neurons. Pharmacol Rev 43: 143-201, 1991

83. Hosseini S, Lee J, Sepulveda RT, Rohdewald P, Watson RR: A randomized, double blind, placebo controlled, prospective, 16 week crossover study to determine the role of Pycnogenol in modifying blood pressure in mildly hypertensive patients. Nutr Res 21:67-76, 2001

84. Hostanska K, Daum G, Saller R: Cytostatic and apoptosisinducing activity of boswellic acids toward malignant cell lines in vitro. Anticancer Res 22:2853-2862, 2002

85. Hung MC, Chen FA, Hsu CH, Chiu CF: The effects of nonsteroidal anti-inflammatory drugs on skeletal muscles. The Sport Journal 5, 2002 (http: //www.thesportjournal.org/2002 Journal/Vol5-no2/NSAID.asp) [Accessed 27 September, 2006]

86. Jachak SM: Cyclooxygenase inhibitory natural products: current status. Curr Med Chem 13:659-678, 2006

87. Jancsó G, Kíraly E, Jancsó-Gábor A: Direct evidence for an axonal site of action of capsaicin. Naunyn Schmiedebergs Arch Pharmacol 313:91-94, 1980

88. Jancso G, Kiraly E, Such G, Joo F, Nagy A: A neurotoxic effect of capsaicin in mammals. Acta Physiol Hung 69:295-313, 1987

89. Jarvinen M: Healing of a crush injury in rat striated muscle. Acta Chir Scand 142:47-56, 1976

90. Jha V, Chugh KS: Nephropathy associated with animal, plant, and chemical toxins in the tropics. Semin Nephrol 23:49-65, 2003

91. Karai L, Brown DC, Mannes AJ, Connelly ST, Brown J, Gandal M, et al: Deletion of vanilloid receptor 1-expressing primary afferent neurons for pain control. J Clin Invest 113: 1344-1352, 2004

92. Karch SB: The Consumer's Guide to Herbal Medicine. Hauppauge, New York: Advanced Research Press, 1999, pp 55-56

93. Keplinger K, Laus G, Wurm M, Dierich MP, Teppner H: Uncaria tomentosa (Wild) DC-Enthnomedicinal use and new pharmacological, toxicological and botanical results. J Ethnopharmacol 64:23-34, 1999

94. Khayyal MT, El-Ghazaly MA, Abdallah DM, Okpanyi SN, Kelber P, Weiser D: Mechanisms involved in the anti-inflammatory effect of a standardized willow bark extract. Arzneimittelforschung 55:677-687, 2005

95. Kimmatkar N, Thawani V, Hingorani L, Khiyani R: Efficacy and tolerability of Boswellia serrata extract in treatment of osteoarthritis on knee-a randomized double blind placebo controlled trial. Phytomedicine 10:3-7, 2003

96. Ko RJ: Adulterants in Asian patent medicines. N Engl J Med 339:847, 1998 (Letter)

97. Kracht M, Saklatvala J: Transcriptional and post-transcriptional control of gene expression in inflammation. Cytokine 20: 91-106, 2002
98. Krivoy N, Pavlotzky E, Chrubasik S, Eisenberg E, Brook G: Effect of salicis cortex extract on human platelet aggregation. Planta Med 67:209-212, 2001

99. Kulkarni RR, Patki PS, Jog VP, Gandage SG, Patwardhan B: Treatment of osteoarthritis with a herbomineral formulation: a double-blind, placebo-controlled, cross-over study. J Ethnopharmacology 33:91-95, 1991

100. Lemaire I, Assinewe V, Cano P, Awang DVC, Arnason JT: Stimulation of interleukin-1 and -6 production in alveolar macrophages by the neotropical liana, Uncaria tomentosa (uña de gato). J Ethnopharmacol 64:109-115, 1999

101. Liu F, Zhang Y, Lau BS: Pycnogenol improves learning impairment and memory deficit in senescence-accelerated mice. J Anti-aging Med 2:349-355, 1999

102. Liu X, Wei J, Tan F, Zhou S, Würthwein G, Rohdewald P: Antidiabetic effect of Pycnogenol French maritime pine bark extract in patients with diabetes type II. Life Sci 75: 2505-2513, 2004

103. Liu X, Wei J, Tan F, Zhou S, Würthwein G, Rohdewald P: Pycnogenol, French maritime pine bark extract, improves endothelial function of hypertensive patients. Life Sci 74:855-862, 2004

104. Luster AD: Chemokines-chemotatic cytokines that mediate inflammation. N Engl J Med 338:436-445, 1998

105. Malmstrom K, Daniels S, Kotey P, Seidenberg BC, Desjardins PJ: Comparison of rofecoxib and celcoxib, two cyclooxygenase-2 inhibitors, in postoperative dental pain: A randomized, placebo-and active-comparator-controlled clinical trial. Clin Ther 21:1653-1663, 1999

106. Marcus D: Willow bark extract, a useful alternative for the treatment of osteoarthritis: comment on the editorial by Marcus and Suarez-Almazor (Reply). Arthritis Rheum 48: 279-280, 2003

107. Marienfeld R, Neumann M, Chuvpilo S, Escher C, Kneitz B, Avots A, et al: Cyclosporin A interferes with the inducible degradation of NF- $\kappa$ B inhibitors, but not with the processing of p105/NF-к B1 in T cells. Eur J Immunol 27:1601-1609, 1997

108. Maroon JC, Bost JW: Omega-3 fatty acids (fish oil) as an antiinflammatory: an alternative to nonsteroidal anti-inflammatory drugs for discogenic pain. Surg Neurol 65:326-331, 2006

109. Meadows M: Why drugs get pulled off the market. FDA Consumer 36:11-17, 2002

110. Meyer S, Kohler NG, Joly A: Cyclosporine A is a non-competitive inhibitor of proteasome activity and prevents NF-к B activation. FEBS Lett 413:354-358, 1997

111. Miller MJS, Ahmed S, Bobrowski P, Haqqi TM: The chondroprotective actions of a natural product are associated with the activation of IGF-1 production by human chondrocytes despite the presence of IL-1 $\beta$. BMC Complement Altern Med 6:13, 2006

112. Mix KS, Mengshol JA, Benbow U, Vincenti MP, Sporn MB, Brinckerhoff CE, et al: A synthetic triterpenoid selectively inhibits the induction of matrix metalloproteinases 1 and 13 by inflammatory cytokines. Arthritis Rheum 44:1096-1104, 2001

113. Moncado S, Gryglewski R, Bunting S, Vane JR: An enzyme isolated from arteries transforms prostaglandin endoperoxides to an unstable substance that inhibits platelet aggregation. Nature 263:663-665, 1976

114. Morrison BW, Christensen S, Yuan W, Brown J, Amlani S, Seidenberg B: Analgesic efficacy of the cyclooxygenase-2specific inhibitor rofecoxib in post-dental surgery pain: a randomized, controlled trial. Clin Ther 21:943-953, 1999

115. Natarajan C, Bright JJ: Curcumin inhibits experimental allergic encephalomyelitis by blocking IL-12 signaling through Janus Kinase-STAT pathway in T lymphocytes. J Immunol 168: 6506-6513, 2002

116. Negri L, Lattanzi R, Giannini E, Colucci M, Margheriti F, 
Melchiorri P, et al: Impaired nociception and inflammatory pain sensation in mice lacking the prokineticin receptor PKR1: focus on interaction between PKR1 and the capsaicin receptor TRPV1 in pain behavior. J Neurosci 26:6716-6727, 2006

117. Nelson AB, Lau BH, Ide N, Rong Y: Pycnogenol inhibits macrophage oxidative burst, lipoprotein oxidation, and hydroxyl radical-induced DNA damage. Drug Dev Ind Pharm 24:139-144, 1998

118. Obremsky WT, Seaber AV, Ribbeck BM, Garrett WE Jr: Biomechanical and histologic assessment of a controlled muscle strain injury treated with Piroxicam. Am J Sports Med 22:558-561, 1994

119. Opal SM, DePalo VA: Anti-inflammatory cytokines. Chest 117:1162-1172, 2000

120. Packer L, Rimbach G, Virgili F: Antioxidant activity and biologic properties of a procyanidin-rich extract from Pine (pinus maritima) bark, Pycnogenol. Free Radic Biol Med 27:704-724, 1999

121. Pahl HL: Activators and target genes of Rel/NF-к B transcription factors. Oncogene 18:6853-6866, 1999

122. Pavlovic P: Improved endurance by use of antioxidants. Eur Bull Drug Res 7:26-29, 1999

123. Peng Q, Wei Z, Lau BHS: Pycnogenol inhibits tumor necrosis factor- $\alpha$-induced nuclear factor kappa B activation and adhesion molecule expression in human vascular endothelial cells. Cell Mol Life Sci 57:834-841, 2000

124. Pepping J: Omega-3 essential fatty acids. Am J Health Syst Pharm 56:719-20, 723-724, 1999

125. Piscoya J, Rodriquez Z, Bustamante SA, Okuhama NN, Miller MJS, Sandoval M, et al: Efficacy and safety of freeze-dried cat's claw in osteoarthritis of the knee: mechanisms of action of the species Uncaria guianensis. Inflamm Res 50:442-448, 2001

126. Plummer SM, Holloway KA, Manson MM, Monks RJL, Kaptein A, Farrow S, et al: Inhibition of cyclo-oxygenase 2 expression in colon cells by the chemopreventive agent curcumin involves inhibition of NF-K B activation via the NIK/ IKK signalling complex. Oncogene 18:6013-6020, 1999

127. Porter V: NSAIDs still under surveillance-celecoxib, caldecoxib, and naproxen have been added to the list of suspects. Medscape Cardiology 9, 2005 (http: //www.medscape.com/ viewarticle/496951) [Accessed 20 Sepember 2006]

128. Pospisilova E, Palecek J: Post-operative pain behavior in rats is reduced after single high-concentration capsaicin application. Pain: Epub 22 June, 2006

129. Psaty BM, Furberg CD, Ray WA, Weiss NS: Potential for conflict of interest in the evaluation of suspected adverse drug reactions. JAMA 292:2622-2631, 2004

130. Pungle P, Banavalikar M, Suthar A, Biyani M, Mengi S: Immunomodulatory activity of boswellic acids of Boswellia serrata Roxb. Indian J Exp Biol 41:1460-1462, 2003

131. Pütter M, Grotemeyer KHM, Würthwein G, Araghi-Niknam M, Watson RR, Hosseini S, et al: Inhibition of smoking-induced platelet aggregation by aspirin and Pycnogenol. Thromb Res 95:155-161, 1999

132. Rahusen FTG, Weinhold PS, Almekinders LC: Nonsteroidal anti-inflammatory drugs and acetaminophen in the treatment of an acute muscle injury. Am J Sports Med 32:1856-1859, 2004

133. Rehman Q, Sack KE: When to try COX-2-specific inhibitors: safer than standard NSAIDS in some situations. Postgrad Med 106:95-106, 1999

134. Reichling J, Schmokel H, Fitzi J, Bucher S, Saller R: Dietary support with Boswellia resin in canine inflammatory joint and spinal disease. Schweiz Arch Tierheilkd 146:71-79, 2004

135. Reuben SS, Connelly NR: Postoperative analgesic effects of celecoxib or rofecoxib after spinal fusion surgery. Anesth Analg 91: 1221-1225, 2000

136. Reynolds JF, Noakes TD, Schwellnus MP, Windt A,
Bowerbank P: Non-steroidal anti-inflammatory drugs fail to enhance healing of acute hamstring injuries treated with physiotherapy. S Afr Med J 85:517-522, 1995

137. Rizzi R, Re F, Bianchi A, De Feo V, de Simone F, Bianchi L, et al: Mutagenic and antimutagenic activities of Uncaria tomentosa and its extracts. J Ethnopharmacol 38:63-77, 1993

138. Rotblatt M, Ziment I: Evidence-Based Herbal Medicine. Philadelphia: Hanley \& Belfus, 2002, pp 114-118

139. Safayhi H, Mack T, Sabieraj J, Anazodo MI, Subramanian LR, Ammon HP: Boswellic acids: novel, specific, nonredox inhibitors of 5-lipoxygenase. J Pharmacol Exp Ther 261: 1143-1146, 1992

140. Safayhi H, Sailer ER: Anti-inflammatory actions of pentacyclic triterpenes. Planta Medica 63:487-493, 1997

141. Sailer ER, Schweizer S, Boden SE, Ammon HP, Safayhi H: Characterization of an acetyl-11-keto- $\beta$-boswellic acid and arachidonate-binding regulatory site of 5-lipoxygenase using photoaffinity labeling. Eur J Biochem 256:364, 1998

142. Sailer ER, Subramanian LR, Rall B, Hoernlein RF, Ammon HP, Safayhi H: Acetyl-11-keto-beta-boswellic acid (AKBA): structure requirements for binding and 5-lipoxgenase inhibitory activity. Br J Pharmacol 117:615-618, 1996

143. Sandoval M, Charbonnet RM, Okuhama NN, Roberts J, Krenova Z, Trentacosti AM, et al: Cat's claw inhibits TNFoproduction and scavenges free radicals: role in cytoprotection. Free Radic Biol Med 29:71-78, 2000

144. Sandoval-Chacón M, Thompson JH, Zhang XJ, Liu X, Mannick EE, Sadowska-Krowicka $\mathrm{H}$ et al: Antiinflammatory actions of cat's claw: the role of NF-к B. Aliment Pharmacol Ther 12:1279-1289, 1998

145. Schmid B, Kötter I, Heide L: Pharmacokinetics of salicin after oral administration of a standardised willow bark extract. Eur J Clin Pharmacol 57:387-391, 2001

146. Schmid B, Lüdtke R, Selbmann HK, Kötter I, Tschirdewahn B, Schaffner W, et al: Efficacy and tolerability of a standardized willow bark extract in patients with osteoarthritis: randomized placebo-controlled double blind clinical trial. Phytother Res 15:344-350, 2001

147. Schweizer S, von Brocke AFW, Boden SE, Bayer E, Ammon HPT, Safayhi H: Workup-dependent formation of 5-lipoxygenase inhibitory boswellic acid analogues. J Nat Prod 63: 1058-1061, 2000

148. Seibert K, Masferrer JL: Role of inducible cyclooxygenase (COX-2) in inflammation. Receptor 4:17-23, 1994

149. Setty AR, Sigal LH: Herbal medications commonly used in the practice of rheumatology: mechanisms of action, efficacy, and side effects. Semin Arthritis Rheum 34:773-784, 2005

150. Shao Y, Ho CT, Chin CK, Badmaev V, Ma W, Huang MT: Inhibitory activity of boswellic acids from Boswellia serrata against human leukemia HL-60 cells in culture. Planta Med 64:328-331, 1998

151. Sharma S, Thawani V, Hingorani L, Shrivastava M, Bhate VR, Khiyani R: Pharmacokinetic study of 11-keto beta-Boswellic acid. Phytomedicine 11:255-260, 2004

152. Sheng Y, Pero RW, Amiri A, Bryngelsson C: Induction of apoptosis and inhibition of proliferation in human tumor cells treated with extracts of Uncaria tomentosa. Anticancer Res 18:3363-3368, 1998

153. Sheng Y, Pero RW, Wagner H: Treatment of chemotherapyinduced leukopenia in rat model with aqueous extract from Uncaria tomentosa. Phytomedicine 7:137-143, 2000

154. Singh G: Recent considerations in nonsteroidal anti-inflammatory drug gastropathy. Am J Med 105:31S-38S, 1998

155. Singh R, Ahmed S, Islam N, Goldberg VM, Tariq M, Haqqi TM: Epigallocatechin-3-gallate inhibits interleukin-1 $\beta$ induced expression of nitric oxide synthase and production of nitric oxide in human chondrocytes. Arthritis Rheum 46: 2079-2086, 2002 
156. Soto L, Martín AI, Vara E, López-Calderón A: Cyclosporin A treatment is able to revert the decrease in circulating $\mathrm{GH}$ and IGF-1 and increase in IGFBPs induced by adjuvant arthritis. Horm Metab Res 33:590-595, 2001

157. Steinberg PN: Cat's claw: medicinal properties of this Amazon vine. Nutrition Science News, 1995 (http: //www.herbalgram.org/herbclip/review.asp?i=41312) [Accessed September 21 2006]

158. Sumpio BE, Cordova AC, Berke-Schlessel DW, Qin F, Chen QH: Green tea, the "Asian paradox, " and cardiovascular disease. J Am Coll Surg 202:813-825, 2006

159. Szallasi A, Blumberg PM: Vanilloid (Capsaicin) receptors and mechanisms. Pharmacol Rev 51:159-212, 1999

160. Talalay P, Talalay P: The importance of using scientific principles in the development of medicinal agents from plants. Acad Med 76:238-247, 2001

161. Tijburg LBM, Mattern T, Foltz JD, Weisgerber UM, Katan MB: Tea flavonoids in cardiovascular diseases: a review. Crit Rev Food Sci Nutr 37:771-785, 1997

162. Tilley SL, Coffman TM, Koller BH: Mixed messages: modulation of inflammation in immune responses by prostaglandins and thromboxanes. J Clin Invest 108:15-23, 2001

163. Van Epps HL: Inflammation control gets fishy. J Exp Med 201:662, 2005

164. Vane J, Botting R: Inflammation and the mechanism of action of anti-inflammatory drugs. FASEB J 1:89-96, 1987

165. Vane JR: Inhibition of prostaglandin synthesis as a mechanism of action for aspirin-like drugs. Nat New Biol 231:232-235, 1971

166. Vane JR: The fight against rheumatism: from willow bark to COX-1 sparing drugs. J Physiol Pharmacol 51:573-586, 2000

167. Vankemmelbeke MN, Jones GC, Fowles C, Ilic MZ, Handley CJ, Day AJ, et al: Selective inhibition of ADAMTS-1, -4 and5 by catechin gallate esters. Eur J Biochem 270:2394-2403, 2003

168. Venkataraman L, Burakoff SJ, Sen R: FK506 inhibits antigen receptor-mediated induction of c-rel in $\mathrm{B}$ and $\mathrm{T}$ lymphoid cells. J Exp Med 181:1091-1099, 1995

169. Venturini CM, Isakson P, Needleman P: Non-steroidal antiinflammatory drug-induced renal failure: a brief review of the role of cyclooxygenase isoforms. Curr Opin Nephrol Hypertens 7:79-82, 1998

170. Vina J, Gomez-Cabrera MC, Lloret A, Marquez R, Minana JB, PallardÓ FV, et al: Free radicals in exhaustive physical exercise: mechanism of production and protection by antioxidants. Life 50:271-277, 2000

171. Wang C, Chung M, Lichtenstein A, Balk E, Kupelnick B, Devine D, et al: Effects of omega-3 fatty acids on cardiovascular disease. AHRQ: 04-e009-1. Rockville, MD: Agency for Healthcare Research, 2004

172. Warner TD, Giuliano F, Vojnovic I, Bukasa A, Mitchell JA, Vane JR: Nonsteroid drug selectivities for cyclo-oxygenase-1 rather than cyclo-oxygenase- 2 are associated with human gastrointestinal toxicity: a full in vitro analysis. Proc Natl Acad Sci U S A 96:7563-7568, 1999

173. Wise M: Pro basketball; health risk stems players' use of painkillers. The New York Times, January 29, 2002

174. Wong MM, Fish EN: Chemokines: attractive mediators of the immune response. Semin Immunol 15:5-14, 2003

175. Yamamoto Y, Gaynor RB: Therapeutic potential of inhibition on the NK-к B pathway in the treatment of inflammation and cancer. J Clin Invest 107:135-142, 2001

176. Yang CS, Wang ZY: Tea and cancer: a review. J Natl Cancer Inst 85:1038-1049, 1993

177. Zandi E, Karin M: Bridging the gap: composition, regulation, and physiological function of the Iк B kinase complex. Mol Cell Biol 19:4547-4551, 1999

178. Zeitlin P: Can curcumin cure cystic fibrosis? N Engl J Med 351:606-608, 2004

179. Zwillich T: Group calls for 2 arthritis drug bans, public citizen says Celebrex, Bextra share Vioxx's problems. (http://www. webmd.com/content/article/99/105336.htm) [Accessed 26 September 2006]

Manuscript received July 31, 2006.

Accepted in final form September 7, 2006.

Address reprint requests to: Jeffrey Bost, P.A.-C., Department of Neurosurgery, Tri-State Neurosurgical Associates-UPMC Presbyterian University Hospital, Suite 5C, 200 Lothrop Street, Pittsburgh, Pennsylvania 15213. email: bostj@upmc.edu. 